\title{
Rome's Decemviral Commission to Greece: Fact, Fiction or Otherwise?
}

\author{
By Ken Moore*
}

Greek and Roman sources from the late Republic, early Principate and beyond report a commission having been sent from Rome to Greece in order to study their laws to help the Romans in reforming their constitution. These are mainly Livy, Dionysius of Halicarnassus and, rather later, Sextus Pomponius; yet, no evidence from the $5^{\text {th }}$ century B.C. can be found to back up their assertions. This paper will explore the evidence and the historiographical reception of these matters to determine whether a new interpretation is possible. It will re-examine previous historiographical arguments, trends in scholarship and debates drawing on a range of sources. Based on the analysis of these, this paper posits that Rome's reported commission to Greece was, in fact, a very real possibility, rather than just a convenient historical fiction, but that the evidence remains inconclusive and divisive.

A number of sources primarily from the late Roman Republic and the early Principate, but also beyond these, report that, in the 5th century B.C., when the patricians sought to reform the laws, a commission was dispatched from Rome to Athens and charged with studying their traditions. They were to return and report their findings so as to aid in these efforts of reform. Apart from accounts in the likes of Livy, Dionysius of Halicarnassus, Strabo and, rather later, Sextus Pomponius, no evidence contemporary with the alleged commission exists to confirm or deny such assertions. Many modern scholars consider this to be an invented tradition, albeit telling of a desire on the part of the Romans to be connected with Classical Greek culture. But was it merely a convenient tale, a myth to shore up Roman legitimacy, or could there be some merit to these claims? This paper explores the evidence and the historiographical reception of these matters in order to determine which interpretation is most plausible.

Before getting into epistemological issues with the sources, let us consider the prevailing position in the current scholarship. As indicated, the most common interpretation is that these stories of Greek involvement with the formulation of the Twelve Tables in post-regnal Rome is that they "have no claim to historicity", as Gruen argues, and that the "legend may have been made up in the late Republic when writers embellished on the parallels to invent an actual trip resulting in an Athenian pattern for Roman legislators". ${ }^{1}$ Certainly, not all modern scholars hold this position and some, like Forsythe (below), consider at least the possibility that there were historical elements to this account. But, according to the dominant trend, it is generally thought that any genuine similarities between Greek and Roman laws must have been derived from contact between the early Romans and Greek colonies in Italy (or

\footnotetext{
*Senior Lecturer in the History of Ideas, Programme Leader, Teesside University, UK.

1. E. S. Gruen, "Romans and Others," in A Companion to the Roman Republic, ed. N. Rosenstein \& R. Morstein-Marx (USA: Blackwell Publishing Ltd, 2010), 468.
} 
possibly too by way of the Etruscans), and/or coincidence, with the construction of a later narrative mythos about the commission to Athens which represented a desire to join-up Roman traditions with Greek ones, perhaps to impart some greater validity to the former by way of the latter. Such a position clearly admits a perceived debt to, and a favourable reception of, Greek thought amongst Roman intellectuals in the Late Republic, however only an imagined connection in reality. Even if it is purely fiction, as Gruen argues, the notion that Rome's most august laws, which formed the very foundation for its entire legal system, obtained inspiration from the Greeks does at least reveal something of the mind-set of Romans of, for example, Livy's era. Is it purely fiction? Firstly, let us consider the sources.

Titus Livius Patavinus (Livy, 64 or 59 BC - AD 12 or 17) indicates in his Histories that, following the Succession of the Plebs who were agitating for better representation, the Republican government considered what course of action to take. This eventually resulted in the Decemvirate that was charged with inscribing the hitherto unwritten laws (c. 451 B.C.). Prior to its formation, they also reportedly dispatched envoys to the Greeks to learn from their legal institutions. Livy writes:

The patricians...declared that no one should propose laws unless he were a patrician. Since they were agreed in regard to the laws, and only differed about the mover, they sent Spurius Postumius Albus, Aulus Manlius, and Publius Sulpicius Camerinus on a mission to Athens, with orders to copy the famous laws of Solon, ${ }^{2}$ and acquaint themselves with the institutions, customs, and laws of the other Greek states.

[and later]...next to these were honoured the three envoys who had gone to Athens, not only that the office might serve to reward them for so distant a mission, but also in the belief that their knowledge of foreign laws would be useful in compiling a new code (III.32.5-7).

Dionysius of Halicarnassus (c. $60 \mathrm{BC}-$ after 7 BC), notably a Greek source, albeit one writing for a largely Roman audience, adds some further detail in his Antiquities of the Romans, saying that the former consul Titus Romilius Rocus Vaticanus advised the following:

The substance of my advice is that you choose ambassadors and send some of them to the Greek cities in Italy and others to Athens, to ask the Greeks for their best laws and such as are most suited to our ways of life, and then to bring these laws here and, when they return, that the consuls then in office shall propose for the consideration of the senate what men to choose as lawgivers, what magistracy they shall hold and

2. Cicero, De Legibus II.59, speaks of the laws of Solon and the Twelve Tables in the same sentence, saying "And when you treat of this Jurisprudence, my brother, we are not so anxious to hear of the laws of Lycurgus, and Solon, and Charondas, and Galencus, nor our Roman Twelve Tables, and popular decrees"; although, he does not explicitly state a connection at this point. 
for how long a time, and to determine everything else in such a manner as they shall think expedient (X.51.5).

He too names those who were sent, as with Livy, saying "the preliminary decree having been drawn up and afterwards confirmed by the populace, the ambassadors who were to obtain the laws from the Greeks were chosen, namely, Spurius Postumius, Servius Sulpicius and Aulus Manlius; and they were furnished with triremes at the public expense and with such other appointments as were sufficient to display the dignity of the Roman state" (X.52.4). And he indicates that later "the ambassadors arrived from Athens and the Greek cities in Italy, bringing with them the laws" (X.54.3). Note that Dionysius includes "the Greek cities in Italy" as ones also to be consulted whereas Livy had only said "other Greek states"; although, Livy's statement could be interpreted to indicate Magna Graecia as well.

According to a parallel tradition, these Greek laws needed some further interpretation. Pliny and Strabo supplement the tale to the effect that an exiled Ephesian philosopher, Hermodorus by name, was summoned to aid in that regard. Pliny (AD 23-79), in his Natural History writes that a "statue of Hermodorus also, the Ephesian, the interpreter of the laws which were transcribed by the Decemvirs, was erected by the public in the comitium" (XXXIV.11). Strabo (64 or 63 BC - c. AD 24) comments too in his Geography that "Hermodorus is reputed to have written certain laws for the Romans" (XIV.1.25). ${ }^{3}$ By the $2^{\text {nd }}$ Century A.D. and thereafter, this version of events appears to have been taken as de rigueur. Sextus Pomponius, in his Enchiridion, preserved in the Pandects (Digest of Justinian) I.2.4, states that:

Afterwards, in order that this condition might not be continued, it was decided that ten men should be appointed by public authority, through whose agency laws should be applied for to the States of Greece, and that the Republic should be founded upon statutory enactments. Those thus obtained were inscribed upon ivory tablets, and placed before the Rostra, so that the laws might be the more clearly understood; and supreme authority in the State was conferred upon said officials for that year, so that they might amend the laws, if it was necessary, and interpret them; and that there should be no appeal from their decisions, as there was from those of other magistrates. They, themselves, observed that something was lacking in these original laws, and therefore during the following year they added two other tablets to them, and for this reason they were called the Laws of the Twelve Tables; and some writers have asserted that a certain Hermodorus, an Ephesian exile in Italy, was responsible for the enactment of the said laws.

This same Hermodorus (of Ephesus) appears to have been a contemporary of Heracleitus (c. 500 B.C.), who is said to have praised him and, given the postulated timeframe for Heracleitus, may not have been alive at the writing of

3. Cicero knew of Hermodorus; see Tusc. Quces. B. v. c. 36.-B. 
the Twelve Tables; although, that is speculative at best. ${ }^{4}$ Even so, there was a Hellenic Greek tradition of sending philosophers, having a close connection with civic virtue, as ambassadors and this not implausible in the case of Hermodorus, whether sent, sent for or whether he came voluntarily, to assist the Romans with their legal issues. ${ }^{5}$

As may be observed from their dates, Livy, Dionysius and Strabo lived approximately around the same time. Those that come later (Pliny and Pomponius) may well have derived their accounts exclusively from these earlier ones. It has thus far proven impossible to locate any sources prior to these in the $1^{\text {st }}$, Greek or Roman, that corroborate this account. We would perhaps expect Diodorus Siculus (1st century B.C.) to have mentioned the commission to Greece in discussing these affairs (Histories, XII. 24-25); but he does not. And neither does Polybius; although, he interestingly notes that, in the $2^{\text {nd }}$ century B.C., Rome did send Decemviral commissions to Greece, in which he himself participated in an advisory capacity, in order to settle constitutional affairs in newly annexed provinces (XXXIX.5.5-6). ${ }^{6}$

Issues with our main primary sources abound. Ab Urbe Condita was an expansive literary opus which was extremely popular and became an 'instant classic' amongst the Romans. Livy's appeal to pathos and patriotic history was in no small part intended to entertain. He simplified, and not always with accuracy, difficult and complex issues for a general readership. He filled his text with sensational vitality in order to make it more interesting and to appeal to his audience's sensibilities. And he stitched together his narrative often by copying wholesale from his sources. From a purely historical standpoint, he was accurate only where his sources were accurate. ${ }^{7}$ Since Livy does not usually name his sources, it is very difficult to assess their validity, especially as regards the commission to Greece.

We can, at any rate, make several observations here. The fact that he, along with Dionysius, records the names of the ambassadors is curious, to say the least. Platner points out that, in Cicero's era, people were not even certain of the names of those who had been sent out in 146 B.C. to assist Memmius in the reorganization of provincial Greece (to which Polybius referred above). He also argues that the names given as commissioners to the Greeks in Livy and Dionysius were derived from the fact that members of the gentes Postumii, Sulpicii and Manlii had been ambassadors to Greece in the $3^{\text {rd }}$ century, and therefore it was deduced that members of these same families must have been

4. G. Forsythe, A Critical History of Early Rome: From Prehistory to the First Punic War (University of California Press: Berkeley, 2006), 210. Heraclitus of Ephesus criticised his fellow citizens because they had banished Hermodorus, the "most estimable man' among them, with the justification that among them 'no one should be the most estimable" (Diels/Kranz 22,121).

5. See E. Z. Lyons Hellenic Philosophers as Ambassadors to the Roman Empire: Performance, Parrhesia, and Power. A dissertation submitted in partial fulfilment of the requirements for the degree of Doctor of Philosophy (Classical Studies) in The University of Michigan, 2011, 1-4 et passim.

6. See too C. Champion, "Empire by Invitation: Greek Political Strategies and Roman Imperial Interventions in the Second Century B.C.E," in Transactions of the American Philological Association 137, no. 2(2007): 264 ff.

7. See "Livy," Johndclare, accessed October 23, 2018, https://bit.ly/2M5wDKv; "Livy (4)," Livius, accessed October 23, 2018, https://bit.ly/2VMDf19. 
the ones who took part in that first embassy. ${ }^{8}$ Furthermore, he suggests that the story of the sending of an embassy to Athens on such an errand was a result of the same tendency amongst the historiographers of these two peoples "to prove the parallelism of their institutions, or at least the imitation of the Greek by the Roman." ${ }^{9}$ And he too dismisses the story as un-historical. Even so, it is possible that these same patrician families may well have provided ambassadors to Greece from the founding of the Republic. We know that ambassadorial legati were always sent by the Senate from amongst their ranks (Cic. c. Vatin. 15), that such was considered a great honour which was conferred only on men of high rank or eminence, primarily from within the Senate itself. ${ }^{10}$ It is easy to imagine certain prominent senatorial families monopolising such a role and it might have even made practical sense as the ambassadorial skills needed could be better fostered if certain families specialised in them, much as with the proxenoi in Greece, who were also typically from amongst the same families. ${ }^{11}$ Be that as it may, it is presently impossible to tell whether or not Spurius Postumius, Servius Sulpicius and Aulus Manlius were in fact those who made up this purported diplomatic mission. Though it is feasible and the fact that their families continued to engage in diplomatic service with the Greeks may bolster such a claim rather than cast doubt upon it.

Yet it is also clear that Livy has not wholly fabricated the tale ex nihilo. The Capitoline Fasti, under the year 303 a.u.c. (449 B.C.), do record that the consuls Appius Claudius and Titus Genucius resigned their offices in order that Decemvirs might be elected and that, in the same year, they were indeed chosen consulari imperio legibus scribundis. ${ }^{12}$ The next entry shows that there were also Decemvirs for the year 304 a.u.c. Assuming the authenticity of this "bare-bones" account, then for two years the Roman government was in the hands of a decemvirate with the highest judicial and executive authority, charged with a special responsibility concerning the laws. Livy will have used records such as these to construct his chronology. Unfortunately, the Fasti mention nothing of the commission to the Greeks in 451 B.C. However, our other ancient writer who corroborates Livy, Dionysius of Halicarnassus, does sometimes give us his sources and they are somewhat more substantial in character. For example, he cites the now lost work of the Roman historian Q. Fabius Pictor (254-201 B.C.) for the Greek origins of the Roman Games (VII.70 ff.). ${ }^{13}$ This is, of course, not a source on the Decemvirate and the commission to Athens but it does serve to illustrate that, prior to Dionysius and

8. S. B. Platner, "The Credibility of Early Roman History," in The American Historical Review, 7, no. 2(1902): 250.

9. Ibid.

10. They were also sacred and inviolable, with magisterial powers, see: Dionys. Hal. Ant. Rom. XI.25; Tac. Ann. I.42; Liv. XXI.10; Dig. 50 tit. 7 s17).

11. The fictional Megillus in Plato's Laws (642B3 ff) is a proxenos to Athens, from a family of such proxenoi, and he explains how he spent much of his youth being educated in Athens, all the better to relate to them diplomatically.

12. "With consular power for inscribing the laws"; CIL. i.2.16. Cf. T. Mommsen, Römisches Staatsrecht (Leipzig: S. Hirzel, 1887-1888), II.1, 682 ff. See J. Ellmore, "T he Purpose of the Decemviral Legislation," in Classical Philology 17, no. 2 (1922): 128-140.

13. See H. Hill, "Dionysius of Halicarnassus and the Origins of Rome," in The Journal of Roman Studies, 51, parts 1 and 2 (1961): 88-93. 
Livy's era, at least one Roman scholar thought that there was a very real Greek influence on fundamentally Roman institutions.

Given the issues with Livy in particular, something further needs to be said concerning the historiographical reception of his account, which was largely accepted as fact until the eighteenth century. The philosopher Giambattista Vico began the assault on Livy through articles in the New Science around 1725. He eventually came to deny the existence of the Twelve Tables altogether. But his views had little impact on the scholarly consensus at the time. ${ }^{14}$ However, by the late $18^{\text {th }}$ century, Gibbon had taken up Vico's cause, writing that due to "national pride, both Livy and Dionysius are willing to believe that the deputies of Rome visited Athens under the wise and splendid administration of Pericles, and the laws of Solon were transferred into the Twelve Tables". ${ }^{15}$ He went on to point out there was no Greek evidence of such a deputation and that any similarity between the Roman laws and those of Solon were only "some casual resemblance". In the early nineteenth century, Livy's accuracy became a subject of wider debate and it was concluded that there was a general absence of notable Greek elements in the Twelve Tables. In his first edition of his History of Rome, Niebhur argued that the commission to Athens had never taken place, eventually admitting (in the second edition of this same opus) that it might have occurred but that it had little observable impact on the final Roman legislation. ${ }^{16}$ Mommsen agreed with that view and his position remains dominant to this day, with more limited debates still arising from time to time. ${ }^{17}$ Wilhelm Ihne, referencing Gibbon, argued that "the whole story of the Greek embassy was a fiction". ${ }^{18}$ Gruen, quoted above, illustrates a typical stance on the matter in the current historiography.

Even so, some scholars such as Ellmore, in the early twentieth century, sought to rehabilitate the view that the commission did, in fact, happen (or could have happened) and they did so with recourse to considerations of constitutional matters versus legal ones, e.g. a politeia (res publicae) in contrast to nomoi (leges). The issue comes down to whether or not the Decemvirs were just producing a code of laws or whether their actions marked a fundamental constitutional change. If the former, then there would have been little need to send a deputation to Athens or anywhere else. If the latter, then such a commission would have been not only desirable but potentially quite necessary. ${ }^{19}$ The distinction between laws and constitution was recognised both by Plato in the appropriately titled Republic (Politeia) and Laws (Nomoi) as

14. See M. Steinberg, "The Twelve Tables and their Origins: an Eighteenth Century Debate," in Journal of the History of Ideas 43, no. 3 (1982): 379-396. The traditional view of Livy as a wholly accurate source of Roman history was supported by Bouchard in his Commentaire sur la loi des Douze Tables in 1803, but it appears to have been a "last gasp" articulation of that position.

15. E. Gibbon, Decline and Fall of the Roman Empire, ed.. F. Fernández-Armesto, vol. 5 (London: London Folio Society, 1987), 252.

16. B. G. Niebhur, The History of Rome, trans. J. Hare and C. Thirlwall (Cambridge, 1828), vol. II, $227 \mathrm{ff}$.

17. T. Mommsen, The History of Rome, trans. W. P. Dickson (London, 1864), I. 289-291.

18. W. Ihne, Early Rome: From the Foundations of the City to its Destruction by the Gauls (New York: C. Scribner's Sons, 1898), 170.

19. Ellmore 1922, 138. 
well as later by Cicero, with clear homage to Plato, in his On the Republic (De re publica) and On the Laws (De legibus). Metaphysics and morality aside, the one is clearly about the laws themselves and the other about the theoretical, structural and operational principles of the state. In his Laws, Plato describes two phases of forming a constitution: the establishment of government officials and the laws which govern their conduct and function (675a). Aristotle goes into greater detail in the Politics, also describing the organisation of the state with regard to the public offices and the rules by which they must govern. ${ }^{20}$ Of course, Plato and Aristotle were producing $4^{\text {th }}$ century articulations that would have been unavailable to any deputation sent from Rome to Athens in the early $5^{\text {th }}$ century, if there was one; but, they do illustrate that such ideas had been in circulation since at least the time of Solon.

Ihne's argument against the "embassy to Athens" bears some further consideration, entailing several key points. He asserted that "no nation of antiquity ever dreamt of forming its civil law after a foreign model" and, as with Gibbon and Mommsen, that there is no resemblance between the laws of the Twelve Tables and the laws of Solon. As Niebhur succinctly agreed, the "laws of Solon did not contain what the Romans wanted". ${ }^{21}$ As well as the lack of any evidence from Greece, Ihne pointed out that the Solonian laws were no longer in effect at that time, rather the Cleisthenic reforms were in place. ${ }^{22}$ His last objection can be countered if we assume that the Romans were specifically interested in Solon's laws, regardless of the fact that those of Cleisthenes were then in place. News travelled slowly in the ancient world and the Romans may have been unaware of Cleisthenes but perhaps had heard of Solon and how he had dealt with a crisis similar to their own. Or they may have been aware of Cleisthenes' reforms and preferred Solon's nevertheless for reasons of their own. The reforms of Solon, which Livy states were being studied by the alleged commission, were definitively of a constitutional type, and indeed the Romans were reportedly experiencing comparable issues having to do with debt, representation and inequality.

In terms of the lack of similarity between the Roman laws and those of Solon, Cicero reported that at least one of Solon's was actually adopted by the Romans, that concerning expressions of grief and wealth at funerals. ${ }^{23}$ It is only a single case of parallelism, of the sort that Gibbon had dismissed as circumstantial with "some rules which nature and reason have revealed to every society". ${ }^{24}$ And he too had cited a lack of Greek evidence for the embassy. But this bears some closer scrutiny. Table Ten, insofar as we have it intact, states:

20. 1239a15; see too $1274 b 38,1278 b 8,1289 a 15,1290 a 7$.

21. Niebhur 1828, vol. I, 315.

22. Ihne $1875,170-71$.

23. De legibus II.23.59, in the 10th Table-de modo sepulturae. There is also the tantalising possibility that Solon himself may have visited Italy during his self-imposed exile (Herodotus I.29), after making his famous reforms, and (who knows?) perhaps that is the actual source of this apparent Greek influence on Roman law.

24. Gibbon Op. cit. 
1. A dead person shall not be buried or burned in the city.

2. ...More than this one shall not do: one shall not smooth a funeral pyre with an axe.

3. ...Expenses of a funeral shall be limited to three mourners wearing veils and one mourner wearing an inexpensive purple tunic and ten flutists...

4. Women shall not tear their cheeks or shall not make a sorrowful outcry on account of a funeral.

5a. A dead person's bones shall not be collected that one may make a second funeral.

5b. An exception is for death in battle and on foreign soil.

6a. ...Anointing by slaves is abolished and every kind of drinking bout ... there shall be no costly sprinkling, no long garlands, no incense boxes...

6b. ...A myrrh-spiced drink...shall not be poured on a dead person.

7. Whoever wins a crown himself or by his property, by honour, or by valour, the crown is bestowed on him at his burial...

8. ...Nor gold shall be added to a corpse. But if any one buries or burns a corpse that has gold dental work it shall be without prejudice.

9. It is forbidden...to build a new pyre or a burning mound nearer than sixty feet to another's building without the owner's consent.

10. It is forbidden to acquire by prescriptive right a vestibule of a sepulchre or a burning mound. ${ }^{25}$

Solon's laws on funerary matters are rather more complete, as we have them preserved from a $5^{\text {th }}$ century inscription and canvassed elsewhere in other primary sources, and there are many notable resemblances with Table Ten. ${ }^{26}$ They state:

These are the laws concerning the dead. Bury the dead person as follows: in three white cloths-a spread, a shroud, and a coverlet-or in fewer, not worth more than 300 drachmas. Carry out [the body] on a wedge-footed bed and do not cover the bier with cloths. Bring not more than three choes of wine to the tomb and not more than one chous of olive oil, and bring back the empty jars. Carry the shrouded corpse in silence all the way to the tomb. Perform the preliminary sacrifice according to ancestral customs. Bring the bed and the covers back from the tomb inside the house.

On the next day cleanse the house first with sea water, and then cleanse all the rooms with hyssop. When it has been thoroughly cleansed, the

25. C. Pharr, (gen. ed.), Ancient Roman Statutes: translation, with introduction, commentary, glossary, and index by Allan Chester Johnson, Paul Robinson Coleman-Norton, Frank Card Bourne (Austin, TX: University of Texas Press, 1961); see too O. J. Thatcher (ed.), The Library of Original Sources, vol. III: The Roman World (Milwaukee, WI: University Research Extension Co., 1901), 9-11.

26. See Plutarch, Life of Solon 21. 
house is to be free from pollution; and sacrifices should be made on the hearth.

The women who come to mourn at the funeral are not to leave the tomb before the men. ${ }^{27}$ There is to be no mourning for the dead person on the thirtieth day. Do not put a wine-cup beneath the bed, do not pour out the water, and do not bring the sweepings to the tomb.

In the event that a person dies, when he is carried out, no women should go to the house other than those polluted [by the death]. Those polluted are the mother and wife and sisters and daughters, and in addition to these not more than five women, the daughters' children and cousins; no one else. The polluted when washed with water poured out [from jugs] are free from pollution. [The next two lines are damaged].

This law has been ratified by the Council and the People. On the third day those who mourn on the anniversary of the death are to be free from pollution, but they are not to enter a temple, and the house is to be free from pollution until they come back from the tomb. ${ }^{28}$

The original laws from the Roman Tenth Table will have been more elaborate; but even the version that we have reveals remarkable similarity with the Solonian ones. Athenian municipal graves were located on the northern side of a wide road, the Dromos, which ran through the double-arched Dipylon Gate (also known as the Thriasian Gate) and (later) on to the Platonic Academy a few miles away, with funerary monuments built into the city walls - effectively outside of the city or near its edge following the reconstruction of 478 B.C. State graves were built on either side of the Dipylon Gate, for the burial of prominent individuals such as notable soldiers and statesmen, including Pericles and Cleisthenes. ${ }^{29}$ The restrictions on female mourning are clearly comparable as are some of the other sumptuary rules. Is it merely coincidence, as Gibbon and others suggest? Or is this the case of a Greek law that the Romans wholly borrowed with minor adaptations? It does no less challenge one of Ihne's criteria, as well as Niebhur's, for rejecting the deputation to Athens. And crucially, Cicero, a noted expert on the law comparable to none, thought that this one at least had been borrowed almost wholesale. Another interesting clue comes with the use of the term poena, specifying a "penalty", as indicated in Aulus Gellius' (Attic Nights XX.1.12) in his quotations from the Twelve Tables. The word comes from Doric Greek, such as would have been spoken in $5^{\text {th }}$ century Taras. And, unless Gellius (c. A.D. 125 - after 180) was quoting from a more contemporary rendition of the Tables, then it corroborates a notable Greek influence (perhaps, but not necessarily, from Magna Graecia) on early Roman legal traditions. ${ }^{30}$

In Plato's Laws we also have some indication that commissions of the sort described by Livy were an actual phenomenon known at least to the Greeks. The character of Cleinias, a Cretan, indicates that the government of Knossos is

27. For similar regulations in the 4th century, see Demosthenes, 43.62.

28. Ioulis on Keos, late 5th cent. B.C. (Dittenberger, Syll. 1218. G).

29. Goette, 2008, 59.

30. Forsythe, 2006, 210. 
planning a new colony and has asked him and nine others, acting not unlike the decemvirate in Rome, "to frame the laws, choosing such as we please, whether taken from our local ones or from those of other countries, making no exception about whether they are foreign, provided only that they are superior". ${ }^{31}$ The commissioners were called syngrapheis, charged with making a report of their findings, based on their deliberations. While this example is fictitious, it appears to have been based on actual practices. ${ }^{32}$ And it is not unreasonable to imagine ancient cultures borrowing useful political ideas from one another in just such a manner. Furthermore, the process of drafting laws as a result of such deliberations, as that described in Plato's Laws, was referred to by Dionysius with the phrase tous nomous syngraphein, which was used in reference to the reports of Greek commissions and may be seen as equivalent to the Latin leges scribere, which appears in the official charge of the Decemvirate from the Capitoline Fasti. ${ }^{33}$ Diodorus Siculus, somewhat echoing Dionysius here in describing such commissions, refers to the Roman Decemvirs as nomographoi (XII.23). The connections here are not entirely tenuous but there are clearly some gaps in our understanding. This nonetheless casts doubt on another of Ihne et al's objections and such fact-finding missions appear to have been an integral part of constitutional reform. As mentioned above, the Romans might not have had to go all the way to Athens to learn more about Greek laws when other sources of such intelligence were available nearer to Rome. The states of Magna Graecia in Italy were much closer at hand (e.g. Cumae, Taras, Crotona, Neapolis) and recourse to those is one possibility that modern commentators admit and which was alluded to by Dionysius and, more obliquely, by Livy.

Were the Decemvirs then composing a new constitution, amending the previous one or just writing down existing laws? I think that we can at least exclude the last option. The Twelve Tables were definitely some kind of lawcode, akin to the laws of Draco or the Cretan Code of Gortyn (with which they bear some similarity) and certainly not a written constitution such as those enjoyed by modern republics. But in the ancient world a "constitution" was more of a theoretical framework of government (oligarchy, monarchy, democracy or "mixed", to use Plato's delineations), the "pattern of the state", rather than a written document. When we take into account the reported struggle of the orders and the successions of the Plebs seeking greater representation, which prompted the necessity of the Decemvirate in the first place, it appears, in Ellmore's words, "that what was contemplated was not a mere reduction of the unwritten to writing nor a mechanical compilation of existing material...[i]t implies that new legislation was intended". ${ }^{34}$ The changes that took place in Rome, both prior to and following the formation of the Decemvirate, were certainly of a constitutional nature-from greater representation of the Plebeian order in government to eventual intermarriage

31. III.702c-d.

32. See F. D. Smith, Athenian Political Commissions (Chicago: University of Chicago Press, 1920), 22.

33. X.3-4; see too Ellmore, 1922, 135.

34. Ellmore, 1922, 129. 
between the orders and the opening up of higher offices to the Plebeians. Much of this appears to have come about piecemeal, following the three famous successions of the Plebs, along with other types of agitation on their part, and neither the Romans themselves nor the fragmentary histories of their early period provide a systematic indication of the process by which these constitutional reforms transpired. It is therefore not possible to determine beyond a shadow of doubt precisely what the Decemvirate was doing and whether they thereby required any input from the Greeks on that matterthough it is tantalisingly suggestive that they were reforming the constitution and did need that input.

Did the deputation to Greece, as reported by Livy, Dionysius etc., actually happen? It is clear that Romans of Livy's era and later believed that it did. There are, as noted, similarities between the surviving Twelve Tables and the laws of Solon. Such a commissions charged with consulting other states in order to effect constitutional changes also appear to have been real phenomena in political practice at the time. And the historical evidence implies that some Greek influence on early Roman legal traditions may have derived from the Western Greeks of Magna Graecia and/or by way of the Etruscans. We have seen how $18^{\text {th }}$ and $19^{\text {th }}$ century scholars quite rightly began to challenge the accuracy of Livy. Perhaps they did so with too much zeal in some places. At best, we can only declare that the commission to Athens could have happened and may very well have happened. Indeed, based on the evidence considered, it seems to me a strong possibility that it was something other than a flattering fiction or concocted mythos. However, without further, more definitive proof to corroborate these ancient assertions, it is ultimately impossible to say with absolute certainty. We should nonetheless keep an open mind on the matter. It may be that Rome's reputed commission to Greece has left hitherto undiscovered 'footprints' to be found in some untranslated papyrus scroll, a lost epigraphic inscription waiting to be turned by an Italic or Attic ploughshare or an un-scanned palimpsest forgotten on some dusty shelf. There is, after all, much to credit in Horace's astute observation that "conquered Greece took captive her savage conqueror and brought her arts into rustic Latium." ${ }^{35}$

\section{Bibliography}

Champion, C. "Empire by Invitation: Greek Political Strategies and Roman Imperial Interventions in the Second Century B.C.E." In Transactions of the American Philological Association 137, no. 2(2007): 255-275.

Dittenberger, W. Sylloge inscriptionum graecarum, 4 vol., Lipsiae apud S. Hirzelium, 1915-24.

Ellmore, J. "T he Purpose of the Decemviral Legislation." In Classical Philology 17, no. 2 (1922): 128-140.

Forsythe. G. A Critical History of Early Rome: From Prehistory to the First Punic War. University of California Press: Berkeley, 2006.

35. Epistles II.1, 156-157; Graecia capta ferum victorem cepit et artes intulit agresti Latio. 
Gibbon, E. Decline and Fall of the Roman Empire. Edited by F. Fernández-Armesto, vol. 5. London: London Folio Society, 1987.

Goette, H. R. Athens, Attica and the Megarid: An Archaeological Guide. Routledge: New York, 2008.

Gruen, E. S., "Romans and Others." In A Companion to the Roman Republic, edited by N. Rosenstein \& R. Morstein-Marx, 459-477. USA: Blackwell Publishing Ltd, 2010.

Hill, H. "Dionysius of Halicarnassus and the Origins of Rome." In The Journal of Roman Studies, 51, parts 1 and 2 (1961): 88-93.

Ihne, W. Early Rome: From the Foundations of the City to its Destruction by the Gauls. New York: C. Scribner's Sons, 1898.

"Livy." Johndclare. Accessed October 23, 2018. https://bit.ly/2M5wDKv.

"Livy (4)." Livius. Accessed October 23, 2018. https://bit.ly/2VMDfl9.

Lyons, E. Z. Hellenic Philosophers as Ambassadors to the Roman Empire: Performance, Parrhesia, and Power. A dissertation submitted in partial fulfilment of the requirements for the degree of Doctor of Philosophy (Classical Studies) in The University of Michigan, 2011.

Mommsen, T. The History of Rome. Translated by W. P. Dickson. London, 1864.

Mommsen, T. Römisches Staatsrecht. Leipzig: S. Hirzel, 1887-1888.

Niebhur, B. G. The History of Rome, Translated by J. Hare and C. Thirlwall. Cambridge, 1828.

Pharr, C. (gen. ed.) Ancient Roman Statutes: translation, with introduction, commentary, glossary, and index by Allan Chester Johnson, Paul Robinson Coleman-Norton, Frank Card Bourne. Austin, TX: University of Texas Press, 1961.

Platner, S. B. "The Credibility of Early Roman History." In The American Historical Review, 7, no. 2(1902): 233-253.

Rosenstein, N. A Companion to the Roman Republic (Blackwell Companions to the Ancient World). London: Wiley-Blackwell, 2010.

Smith, F. D. Athenian Political Commissions. Chicago: University of Chicago Press, 1920.

Steinberg, M. "The Twelve Tables and their Origins: an Eighteenth Century Debate." In Journal of the History of Ideas 43, no. 3 (1982): 379-396.

Thatcher, O. J. (ed.) The Library of Original Sources, vol. III: The Roman World. Milwaukee, WI: University Research Extension Co., 1901. 